\title{
Taiwan i kort snor
}

\section{Anders Jerichow}

\section{Hvis taiwanerne ikke accepterer Beijings dogme om ét og kun ét Kina', vil supermagten på fastlan- det fortsat true med sine våben}

Var det ikke vor tidligere statsminister Poul Schlüter, der opsummerede sine indtryk fra et besøg i folkerepublikken Kina sådan, at "de er jo meget ... kinesiske"? Umuligt at komme udenom. Meget kinesiske. Det er de også i ø-samfundet Taiwan, men hvad straks mere kompliceret er - de er også meget 'taiwanske'. Og det er de ikke meget for at høre ovre på fastlandet.

Måske er det noget med ulykkelig kærlighed. Kina er forelsket i Taiwan, men Taiwan er ikke for alvor forelsket i Kina. Og Kina vil ikke nøjes med at være gode venner - det vil forenes i sjæl og legeme. Men hvordan er det nu: Kan man tvinges til kærlighed? Kan Taiwan?

Eller også er det noget med ondt i selvopfattelsen. Selv en supermagt kan ømme sig, hvis en lilleput jokker den over tæerne. Taiwan laver ikke andet.

Kinas Kommunistiske Parti hævder inde på fastlandet, at kinesere har det bedst under styring oppe- fra - Taiwan viser til overflod, at dets egne kinesere trives storartet med demokrati.

Det store fastlands-Kina med 1,3 milliarder indbyggere forsøger 'for folkets egen skyld' at opretholde censur. Det lille Taiwan med 23 millioner minder om, at i hvert fald $\varnothing$ kinesere har det strålende med ytringsfrihed. Kina vil gerne have monopol på at repræsentere 'kinesere' over alt. Men Taiwan provokerer hele tiden, allerede ved at være 'meget kinesisk' - bare på en irriterende, vellykket måde.

Jaushieh Wu og Tang Shaocheng, to vennesæle forskere på Chengshiuniversitetet uden for Taipei, vil ikke acceptere en henvisning til Stockholm-syndromet - dét med, at gidsler risikerer at blive forelsket $\mathrm{i}$ deres gidseltager.

Tang Shaoucheng vil slet ikke mene, at hverken han selv eller Taiwan er et gidsel. Men at han er vild med Beijing ovre på fastlandet, dét skal ikke være nogen hemmelighed. 
Således ikke kollegaen Jaushieh Wu. Han er bare glad for sin frihed $i$ Taiwan.

De er forskere på samme universitet. Landsmænd i samme samfund. Vælgere i samme demokrati. Og deres samfund har alle en stats karaktertræk - en regering, en folkevalgt regering i modsætning til de totalitære magthavere på fastlandet, et eget forsvar med egen værnepligt, et eget politi, et eget uddannelsessystem, en udenrigspolitik med egne repræsentationer over det meste af verden, en fed økonomi, en masse grisefarmere, der ligesom de danske ikke aner, hvad de skal stille op med gyllen, en gevaldig opsparing og 23 millioner indbyggere, hvoraf det helt overvejende flertal absolut ikke drømmer om at blive regeret af Beijing.

Taiwan provokerer hele tiden - allerede ved at være 'meget kinesisk', bare på en irriterende, vellykket måde.

Og så er deres samfund alligevel ikke en stat, ikke et uafhængigt medlem af FN. For dét vil magthaverne inde på fastlandet ikke tillade. Så bliver de ikke bare skuffet - de bliver i ravende krigshumør.

Men det skal vi, omverdenen, slet ikke blande os i, siger Tang Shaoucheng, den Beijing-tro af de to forskere. Han er godt træt af, at verden udenfor - ikke alene uden for Taiwan, men uden for det, han kalder Kina, som i hans øjne omfatter Taiwan - stikker sin næse i kinesiske an- liggender. Nævn bare Nobels fredspris, der sidste år gik til forfatteren og systemkritikeren Liu Xiaobo inde på fastlandet, så ligner Tang Shaoucheng én, der netop har sat tænderne i en overgæret dessert.

Helt sådan ser den anden forsker, Jaushieh Wu, ikke på sagen. Han synes, det er en stolt fornemmelse, at han og kollega Tang Shaoucheng i al åbenhed kan være så fundamentalt uenige - det ville de ikke kunne i Beijing. Han pointerer, at Taiwans indbyggere ifølge alle målinger føler sig mere og mere som taiwanere, ikke som en del af fastlandet, og de har absolut ingen ønsker om at komme under bosserne i Beijing.

Det er hans Beijing-tro kollega Tang Shaoucheng ikke faktuelt uenig i. Men hvem ved, hvad fremtiden bringer? Han anbefaler, at man ikke forveksler det politiske med det kulturelle. For kulturelt er Taiwans indbyggere kinesiske, ingen tvivl om det. Politik er noget andet, og det skal Kina nok finde ud af selv. Siger Tang Shaoucheng.

\section{Talkshows som trækplaste}

Ja, politik er noget andet. Det synes den million kinesere, som årligt besøger Taiwan, også. "Hvad vil du gætte på, at de ser som deres største fornøjelse i Taiwan”, spørger Janushieh Wu. "Du gætter det ikke - talkshows!

Yes, talkshows. Det er blevet den store dille for turisterne fra fastlan- 
det at se taiwanske tv-shows, hvor magthavere bliver grillet for åben skærm. Mageløst, dét sker ikke hjemme i Beijing.

Set fra Taipei kan det hele forekomme lidt uvirkeligt. Midt i byen står skyskraberen '101', der indtil sidste år var verdens højeste, men også med skyskrabere er der altid én, der vil prale af en større, nu i Dubai. Men alligevel.

Taipei har alting, kan alting. For tyve år siden var det her, man lavede plastikdippedutter, hvis man ikke blev i sine rismarker eller sin grisesti. I dag laver man høj-elektronik. Dengang for tyve år siden var der samlebåndsfabrikker i hver en baggård. I dag udvikler man tingene $\mathrm{i}$ Taiwan, men får produceret sine sager i lavlønssamfund, også inde på fastlandet, hvor Taiwan faktisk er blandt de største investorer i kystprovinserne.

I dag er der højhastighedstog i Taiwan, og togene kører til tiden. Der er offentlige biblioteker og børnevaccinationer, desværre også dødsstraf, tonsvis af gadekøkkener, ludere og lommetyve. Det hele er præcis så dynamisk, som det vel må være, når man kører med en økonomisk vækst på nærmere 11 end 10 procent om året.

Det ligner godt nok en stat.

Nu kunne der selvfølgelig stikke noget under ... de taiwanske kinesere kunne sidde på al 'kinesisk' olie, alt ordentlig drikkevand, de bedste mineraler, det historiske land?
Nej, nej, nej. Det er ikke til at øjne en rationel, kun en psykologisk eller en forsmået stormagts grund til, at Beijing nægter at lade de 23 millioner på Taiwan få selvbestemmelse og slippe ud af fastlandets greb. Taiwanerne har ingen af de ressourcer, Kina mangler. Slet ikke de råvarer, som Beijing støvsuger andre samfund, fx i Afrika, for at skaffe sig.

Vi snakker om en beskeden subtropisk $\varnothing$, mindre end Danmark, men med en uoverskuelig mængde bjerge, 100 bjergtoppe over tre kilometers højde, og lige som Fastlandskina afhængig af olie og alt muligt andet udefra.

Tre generationer er vokset op i de 64 år, siden øen blev behersket fra Beijing - og Beijing havde tidligere kun haft magten over øen i fire år. Før dét var Taiwan besat af Japan i et halvt århundrede. Men tre generationer er det siden, at nogle hundrede tusinde 'borgerlige' kinesiske nationalister flygtede ud til den forrevne $\varnothing$, halvanden hundrede kilometer fra kysten, fordi kommunisterne vandt borgerkrigen og tog magten på fastlandet. Til gengæld tog flygtningene magten over de seks millioner taiwanere, der boede på øen i forvejen.

Nogenlunde samtidig tog Finland imod store bølger flygtninge fra Karelen, som Sovjetunionen besatte. Gør Finland i dag krav på Karelen? Nej. Vil flygtningene hjem? Næh, det vil de ikke. Og det vil de sidste kinesiske overlevende fra flugten fra 
fastlandet næppe heller i dag. Der er for længst bygget nye huse, nye byer, hvor flygtningene kom fra; de gamle nøgler duer ikke. Og børnebørnene til de fastlandskinesere, som i 1949 drog ud til Taiwan, giver aldrig udtryk for, at de vil tilbage til det, som bedsteforældrene forlod.

For tyve år siden opfattede kun 20 pct. af befolkningen sig som taiwaner snarere end kinesere. I dag er det over 50 procent, der ser sig selv som 'taiwanere', og kun fem procent insisterer på at kalde sig 'kinesere'.

En lang række andre nye stater er i mellemtiden dukket op på verdens kort. Senest har det sydlige Sudan hvor Kina henter store mængder olie - løsrevet sig ved folkeafstemning. Andre nye stater: Bangladesh. Eritrea. Østtimor. Store og små og mange flere. Det tidligere Jugoslavien er splittet op i Slovenien, Bosnien-Hercegovina, Kroatien, Makedonien, Montenegro, Serbien, Kosovo. $\mathrm{Og}$ verden råber på en ny stat $\mathrm{i} \mathrm{Pa}-$ læstina. Hvad er så problemet i Taiwan, om man må spørge?.

Taiwanerne føler i dag, at de har fået et trygt sted at kalde 'hjemme'.

Men nogle, fx Taiwans Folkelige Demokratiske Parti, synes det er et problem, at Kina truer med raketbombardementer, hver gang partiet taler om uafhængighed.

Andre synes, det er et problem, at Taiwan ikke kan modernisere sin forfatning og slet ikke dens paragraf 4, der stadig taler om 'ét Kina', skønt ethvert skolebarn ved, at der er i hvert fald er to - for så rumsterer de med våbnene inde på fastlandet igen.

Det er ikke kun paragrafrytteri. I vinter skulle 14 taiwanere udvises fra Filippinerne - der ligesom de fleste lande ikke anerkender Taiwan som (derfor) sendte dem lige i favnen på myndighederne inde på fastlandet. Hvad skulle de dér?

\section{Republic of China}

Vel, nu er det måske heller ikke for smart, at det regerende parti på - eller i? - Taiwan selv taler om 'ét land' i sine statutter, og at Taiwan officielt kalder sig 'Republic of China' og således historisk har gjort krav på at repræsentere hele Kina med fastlandet og Taiwan og hele molevitten. En kende overmodigt.

Dertil er der to ting at sige. Det ene, at ikke engang nationalist- og regeringspartiet Kuomintang længere taler om ét Kina, fordi det synspunkt ikke har vælgernes gunst. Det andet er, at Taiwan slet ikke kan tage et andet navn, finde en ny nationalmelodi og lave en ny grundlov.

Der er ikke aktuelt, siger Tang Shaocheng.Det må vi ikke, siger Jaushieh Wu. For så truer Kina igen.

Taiwan er blevet alle fornægtelsers moder. I de første 30-40 år sagde Taiwans regering under Kuomintang-partiet - som dengang opretholdt en undtagelsestilstand og selv skulle presses til demokrati - nej til 
kontakt med fastlandet, nej til forhandlinger og nej til kompromis. Og de gamle magthavere med en fortid og en tabt borgerkrig på fastlandet gik rundt og håbede, at kommunisterne inde i Beijing en dag ville bukke under.

I 1987 gav man første gang de gamle veteraner fra borgerkrigen grønt lys til at besøge familie på fastlandet, og demokratiet satte frø. I dag kommer 3.000 fastlandskinesere hver dag den anden vej - til Taiwan, og de gamle nej'er er ændret til tre nye, som i dag udgør den officielle terrorbalance mellem Fastlandskina og Taiwan - nej til genforening, men også nej til uafhængighed og nej til brug af magt.

Sagt på anden vis: Hvis bare taiwanerne holder bøtte med, at de i al diskretion har etableret en stat, og undertrykker 'u-ordet' - uafhangighed - så vil Beijing udskyde princippet om genforening og lade våbnene tie.

Pudsig måde, i øvrigt, at hævde et familieskab: "Hvis I bliver for selvstændige, slår vi jer ihjel!”.

Faktisk har Taiwan én skat, Kina gerne vil have. Den står i National Palace Museum i Taipei. Tusindvis af de ypperste kunstgenstande, som kinesiske kejsere i århundreder lod indsamle til deres egne fornøjelse i den hemmelige by i Beijing. Bronze, porcelæn, billedkunst, keramik, ædelstene, en fabelagtig samling af de mest uvurderlige kunstgenstande, som havde en ejendommelig skæbne på fastlandet. Kejserne ville have kunstskatten for sig selv helt indtil begyndelsen af 1900-tallet. Under de to japansk-kinesiske krige var hele den prægtige samling pakket ned. Den blev kørt rundt i sikre byer i omkring tredive år, før nationalisterne tog alle kasserne med den kinesiske kulturarv med sig ud til Taiwan.

\section{Tyveri eller kulturværn}

Tyveri, siger Beijing. Taiwan siger: I skulle hellere prise jer lykkelige, at vi passede på skatten - under den kommunistiske kulturrevolution i 1970'erne ville Maos kone og hendes venner have smadret disse kulturværdier på fastlandet.

$\mathrm{Nu}$ præsenteres samlingens ufattelig mange sager på skift; vil man se det hele, skal man forbi flere gange om året i en halv snes år. Kunne man forestille sig en handel: Beijing får skatten eller dele af den - og Taiwan får sin frihed?

Ingen stiller spørgsmålet, ingen tilbyder et svar, hverken hér eller dér.

Det er vist meget kinesisk. Men også taiwansk.

Anders Jerichow er kronikredaktør på Politiken. Han var i foråret 2011 inviteret til Taipei af Taiwan. 